\title{
Antimycobacterial evaluation of some medicinal plants used in plateau State of Nigeria for the treatment of tuberculosis
}

\author{
Nvau, J. B ${ }^{1}$, Oladosu, P. $O^{2}$, Orishadipe, A. $T^{2}$. \\ ${ }^{1}$ Department of Minerals Resources Engineering, Plateau State Polytechnic, Barkin Ladi, \\ Plateau state, Nigeria. \\ ${ }^{2}$ National Institutes for Pharmaceutical Research and Development, Abuja Nigeria.
}

\begin{abstract}
Tuberculosis (TB) continues to be a devastating disease worldwide in the $21^{\text {st }}$ Century and it is believed that one third of the World's populations are infected. 22 Countries are responsible for over $80 \%$ of the global TB burden, Nigeria is rank $4^{\text {th }}$ and have the highest burden in Africa. A number of anti tuberculosis drugs are ineffective against this disease due to the emergence of resistance strains. As part of the effort in developing a new anti tuberculosis agent, we decided to interact with traditional medicine practitioners of the Plateau region on their approach to the management of TB. A total of fourteen (14) plants representing nine families were identified as the most often used plants to manage TB symptoms in the region. The plants materials were extracted using $70 \%$ aq. methanol and the extracts obtained after concentration were screened against BCG. The results of the assay showed that $56 \%$ of the plants screened had MICs within the range of $800 \mu \mathrm{g} / \mathrm{ml}$ to $2000 \mu \mathrm{g} / \mathrm{ml}$ and as such had antimycobacterial activity. These plants are potential sources for herbal drugs for exhibiting these strong inhibitory properties and could also provide leads to tuberculosis drug development.
\end{abstract}

Keywords: tuberculosis, antimycobacterial, herbal drugs.

\section{INTRODUCTION:}

Tuberculosis (TB) remains a leading cause of mortality worldwide and infects a third of the world's population. The world health organization (WHO) estimated that 9 million new cases and 3 million TB related death occur annually ((Raviglione et al., 1995). The largest number of mortality and new cases occur in South Eastern-Asia region, which accounted for $34 \%$ of the incident cases globally ((Global tuberculosis programme, WHO report 1998). The estimated incident in sub-Sahara Africa is nearly twice that of South-Asia countries. The less develop countries are worse hit with Africa having the highest burden, as a result WHO declared TB to be a global burden in 1993. 22 countries, mostly in Africa and Asia are responsible for over $80 \%$ of the global TB (Global tuberculosis Control, WHO report 2007).

Nigeria is rank $4^{\text {th }}$ among the 22 countries and has the highest burden in Africa. The $\mathrm{WHO}$ also estimated that incidences of $123 / 100,000$ of new cases of TB occurred in 2005 in Nigeria, this situation is alarming Global tuberculosis Control. WHO report 2007). The combination of long treatment duration (6-9 months), increase in multidrug resistance strain and synergy with HIV are the driving factors of this trend. Therefore, there is urgent need to source for new and more effective anti-TB from natural/synthetic sources.

Traditional medicine practice has been known for centuries in many parts of the World. The drug of choice is mostly plants extracts (Sofowora, 1984). The biodiversity of Plateau State of Nigeria is rich in flora that offer great possibilities to search for Natural product with anti-mycobacterial potential and that may offer different mode of action in its activity against the bug. The state has unique climate and weather. For this reasons, we attempt to search for anti tuberculosis from plants, exploiting the traditional medical practices of the indigenes. Fourteen crude extracts obtained from fourteen plants belonging to nine families were screened against BCG.

Pavetta corymbosa had been previously reported by Weniger, et al (2004) to possess anti plasmodium activities which further supported the claimed by the traditional healers for its use in treating malaria fever. Canarium schweinfurthii Engl is the next best with a MIC of $1000 \mu \mathrm{g} / \mathrm{ml}$, this suggested that it had broader antibacterial spectrum, in comparison to the previous antioxidant and antimicrobial studies of the essential oil of the plants (Obame et a,I 2007). Piliostigma 
thonningii Schum and Syzygium guineense (Willd.)Dc had anti-mycobacterial activities as well as antibacterial (Akinpelu and Obuotor, 2000; Djoukeng et al, 2005). Also literatures have shown that most of the plants in these studies have anti bacterial activities (Medicinal plants of Nigeria, North central Zone, 2006).

\section{MATERIALS AND METHODS}

Plants material were collected in February 2009 in the central zone of plateau (Nigeria) and identified by the herbarium staff of the department of medicinal plant research and traditional medicine. The voucher specimens were deposited in the herbarium for future reference. Fourteen species were studied, the plants were collected and air dried immediately. A list of the plants part tested is presented in Table 1.

Extractions of plants parts: The powdered plant materials $(10 \mathrm{~g})$ were extracted in $100 \mathrm{ml}$ of $70 \%$ aqueous methanol, on a mechanical shaker for 24 hours at room temperature. The extracts were filtered and the filtrates evaporated at a reduced temperature under vacuum. The residual aqueous solution were thereafter, lyophilized on a bench top freeze dryer. The weight of the extracts obtained and screened against BCG are as indicated in Table 2.

Determination of MIC:Determination of antitubercular activity against Mycobacterium tuberculosis $\left(\mathrm{H}_{37} \mathrm{Rv}\right)$ was carried out as described by Clifton Barry III laboratory, TRS, NIAID, USA (9). This was accomplished using the micro well serial dilution method. A $1 / 10$ dilution of the test extract/compound in DMSO was made in the media; $50 \mu l$ of media was

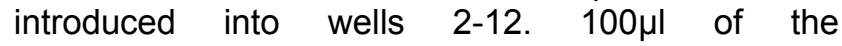
extract/compound was delivered into well $1,50 \mu$ was taken from well 1 and delivered into well 2 after through mixing $50 \mu$ l was transferred from well 2 to 3 and the procedure was repeated through to well 12 and from well was $50 \mu \mathrm{l}$ discarded. Thereafter, $50 \mu \mathrm{l}$ of inoculums was added to all wells and it was incubated for 7 days. DMSO and ethambutol were use as control and standard drug respectively.

Table 1. Plants used in Plateau state of Nigerian traditional medicine.

\begin{tabular}{|l|l|l|l|}
\hline BOTANICAL NAME OF PLANT & FAMILY & $\begin{array}{l}\text { PART } \\
\text { USED }\end{array}$ & TRADITIONAL THERAPEUTIC USES \\
\hline Pavetta corymbosa (DC) F.N. Williams & Rubiaceae & $\begin{array}{l}\text { Leaves and } \\
\text { twist }\end{array}$ & $\begin{array}{l}\text { antimicrobial, } \\
\text { wound,Fever, Respiratory disorder }\end{array}$ \\
\hline Pavetta owariensis P. Beav. & Rubiaceae & Stem bark. & Fever, Cough, Mental disorder. \\
\hline Canarium schweinfurthii Engl. & Burseraceae & Leaves & $\begin{array}{l}\text { Wound, Cough, Stimulant, Sexual } \\
\text { infection }\end{array}$ \\
\hline Cassia mimosides. & caesalpinioideae & Whole plant & Fever, Cough, diarrhea, rheumatism \\
\hline Piliostigma thonningii Schum. & caesalpinioideae & Seed Pods & $\begin{array}{l}\text { Dysentery, } \\
\text { Wound }\end{array}$ \\
\hline Gardenia erubescens Stapf and Hutch & Rubiaceae & Root bark & Antiviral, syphilis, fever, Cough \\
\hline Syzygium guineense (Willd.)Dc & Mytaceae & Root bark & Amenorrhea, Abdominal pain, Cough \\
\hline Vitex dononia & Verbenaceae & Stem bark & $\begin{array}{l}\text { Cough, } \\
\text { leprosy }\end{array}$ \\
\hline Parkia biglobosa (Jacq.) R.Br.exG.Don & Mimosaceae & Stem bark & Leprosy, Cough, Gonorrhea. \\
\hline Erythrina senegalensis & leguminosae & Leaves & $\begin{array}{l}\text { Diuretics, } \\
\text { toothaches }\end{array}$ \\
\hline Terminalia glaucescens Planch.ex.Benth & Combretceae & Leaves & Cough, fever, Stomach pain \\
\hline Maytenus senegalensis(lam).Exell & Celastrceae & Roots & Cough, Infection, Fever \\
\hline Boswellia dalziellii Hutch & Burseraceae & Stem Bark & Dermatitis, eczema Cough \\
\hline Carissa edulis Vahl & Apocynaceae & Roots & Tonic, Stimulant, Cough \\
\hline
\end{tabular}


Table 2. Minimum inhibitory concentration and yield of the plant extracts from the $10 \mathrm{~g}$

\begin{tabular}{|l|l|l|}
\hline BOTANICAL NAME OF PLANT & $\begin{array}{l}\text { WEIGTH } \\
\text { EXTRACTS (g) }\end{array}$ & $\begin{array}{c}\text { MINIMUM CONCENTRATION } \\
\text { CONITIRY }\end{array}$ \\
\hline Pavetta corymbosa (DC) F.N. Williams & 1.20 & 800 \\
\hline Pavetta owariensis P. Beav. & 1.40 & 1800 \\
\hline Canarium schweinfurthii Engl. & 1.50 & 1000 \\
\hline Cassia mimosides & 1.25 & 1200 \\
\hline Piliostigma thonningii Schum. & 1.03 & 2000 \\
\hline Gardenia erubescens Stapf and Hutch & 1.20 & 3850 \\
\hline Syzygium guineense (Willd.)Dc & 1.20 & 1200 \\
\hline Vitex dononia & 1.40 & 1500 \\
\hline Parkia biglobosa (Jacq.) R.Br.exG.Don & 1.35 & 2450 \\
\hline Erythrina senegalensis & 1.10 & 1200 \\
\hline Terminalia glaucescens Planch.ex.Benth & 1.25 & 1300 \\
\hline Maytenus senegalensis(lam).Exell & 1.00 & 3800 \\
\hline Boswellia dalziellii Hutch & 1.80 & 5000 \\
\hline Carissa edulis Vahl & 0.60 & 3650 \\
\hline
\end{tabular}

\section{RESULTS AND DISCUSSION}

The profile of the medicinal plants used in this study is shown in table 1.The choice of the solvent system used in the extraction was deliberate, since this is the closest solvents to what is used by most traditional healers. The result of the anti- mycobacterium activity of the crude extracts revealed that only Nine plants (Pavetta Corymbosa, Canarium schweinfurthii Engl, Piliostigma thonningii Schum, Syzygium guineense, Vitex dononia, Erythrina senegalensis, Pavetta owariensis P.Beav,Terminalia glaucescens Planch. Ex Benth, Cassia mimosides) inhibited the growth of the bacterium with minimum inhibitory concentration within the range of $800 \mu \mathrm{g} / \mathrm{ml}$ to $2000 \mu \mathrm{g} / \mathrm{ml}$. The other five plants (Gardenia erubescens Stapf and Hutch, Pirinari centrifiolium, Maytenus senegalensis (lam).Exell, Boswellia dalziellii Hutch, Parkia biglobosa (Jacq.)R.Br,exG Don. and Cassia mimosides ) had MICs above $2500 \mu \mathrm{g} / \mathrm{ml}$.

This study substantiates the claim/use of the evaluated plant materials by traditional healers for the treatment of tuberculosis. The bioassay screening showed over $64 \%$ of the plant extracts had activity $\leq 2000 \mu \mathrm{g} / \mathrm{ml}$. Those with higher MICs cannot equally be ruled out as these may be sources of prodrugs that may produce better activity in vivo or if screened by other technique may equally give better results. Further work is in progress on some of these plants that had MIC less than $1500 \mu \mathrm{g} / \mathrm{ml}$ with the aim of isolating the active components via bioassay guided isolation.

\section{ACKNOWLEDGMENT}

The authors are grateful to the National Institute for Pharmaceutical Research and Development Abuja for providing some of the material and equipment for this work. We would like to appreciate the ethno botanist of the Department of Medicinal Plants research and Traditional medicine, NIPRD, Abuja for identified the plants used in this work

\section{REFERENCES}

Akinpelu, D. A. and Obuotor, E. M. (2000), Antibacterial activity of Piliostigma thonningii stem bark. Fitoterapia.

Djoukeng, J. B., Abou-Mansour, E., Tabacchi, R., Tapondiou, A. I., Bouda, H., Lontsi, D. (2005). Antibacterial Triterpenes from Syzygium Guineense. Journal of ethnopharmacology. Pp 283-286.

Global Tuberculosis Programme. In. Global tuberculosis control report (1998). Geneva: World Health organization. 237.

Global Tuberculosis Control: Surveillance, planning, Financing. WHO report (2007). Geneva, World Health Organization (WHO/HTM/TB/2007.376

Medicinal plants of Nigeria. North central Zone (2006). Compiled and Published by Nigeria Natural medicine Development Agency. vol 1. Pp 1-45.

Obame, L. C., Koudou, J., Kumulungui, B. S., Bassole, I. H. N., Edou, P., Ouattara, A. S., and Traore, A. S., (2007). Antioxidant and antimicrobial activities of Canarium shweinfurthii Engl. Essential oil from Centrafrican Republic. African Journal of Biotechnology. Vol. 6 (20). Pp 2319-2323.

Sofowora, A. (1984). Medicine plants and traditional medicine in Africa. John Willey and Chichester

Weniger, B, Senecheau, C. V., Adjobimey, T., Gbenou, J., Moudachirou, M., Brun, R., Anton, R. and Sanni, A. (2004). Evaluation of ethnobotanical selected Benin medicinal plants for their in-vitro anti plasmodial activity. Journal of ethnopharmacology. Vol. 90. 2-3. Pp 279-284.

Raviglione, M. C., Snider, D. E. Jr, Kochi, A.. Global epidemiology of tuberculosis: Morbidity and mortality of a worldwide epidemic. JAMA1995; 273(3):220-6. 